\title{
Identification of the Relationship Between Life Satisfaction and Narcissism Levels of University Students
}

\author{
İzzet Karakulak ${ }^{1} \&$ Ünsal Tazegül ${ }^{2}$ \\ ${ }^{1}$ School of Physical Education and Sport, Mardin Artuklu University, Mardin, Turkey \\ ${ }^{2}$ School of Physical Education and Sport, Iğdır University, Iğdır, Turkey \\ Correspondence: İzzet Karakulak, School of Physical Education and Sport, Mardin Artuklu University, Mardin, \\ Turkey. E-mail: izzetkarakulak@gmail.com
}

Received: January 12, 2020

Accepted: February 28, 2020

Online Published: June 11, 2020

doi: $10.5539 /$ ies. $13 \mathrm{n} 7 \mathrm{p} 40$

URL: https://doi.org/10.5539/ies.13n7p40

\begin{abstract}
The objective of this study is to identify the relationship between life satisfaction and narcissism levels of students of the Physical Education and Sports School of Mardin Artuklu University located in southeastern Turkey. In the study, Satisfaction with Life Scale and Narcissistic Personality Inventory were employed in order to collect data. Sample of the study is comprised of a total of 155 Physical Education and Sports School students who voluntarily agreed to participate in the study. 56 participants were female and 99 participants were male. In the data analysis of this research, SPSS 20.0 software was utilized. Independent Samples T-Test, One-way Analysis of Variance (ANOVA) and correlation analysis were used in data analysis. At the end of the statistical analysis, it was found that female students had quantitatively higher narcissistic personality and life satisfaction scores than male students. Thus, it was inferred that female students behaved more narcissistically and were more engaged with life. However, along with the comparison of students' narcissism and life satisfaction scores particularly on the basis of departments of Physical Education and Sports School at which students were enrolled, it was ascertained that there was no statistically significant difference in either narcissism scores or life satisfaction scores.
\end{abstract}

Keywords: narcissism, life satisfaction, university students

\section{Introduction}

Upon the etymological analysis of the concept of narcissism, it is discerned that it originates from the word 'narke' which means obtuseness or numbness (Tazegül, 2018a). Individuals who developed narcissistic personalities believe that they are more distinguished, special and prominent than other people. By virtue of this thinking, they are inclined to perceive themselves to be superior to other human beings (Tazegül \& Ferah, 2016). The concept of narcissism originates from Narcissus who, according to Greek mythology, fell in love with his own reflection upon seeing it on the water and devoted his life to watching this reflection that would be his unattainable love (Tazegül, 2018a; Timuroğlu, 2005). In competitions in which narcissist sportspeople fail, they attribute their failure to reasons such as referee's decisions, errors in rules, spectators and coach's wrong tactics. They do not believe that they lost the competition on account of their own faults (Tazegül, 2018a; Gürkan et al., 2018). Studies performed on narcissistic personality found that individuals who developed narcissistic personalities had high levels of self-confidence (Campbell et al. 2004) and were keen on showing off and flaunting (Saydam, 1996; Morf et al., 2001). Narcissistic people feel venerable and prestigious only if they are able to display and present their superiority to others and receive their admiration. Contrary to other human beings, narcissistic people do not really mind being liked and cared. Accordingly, in order to protect their self-respect and not to have any failure, narcissistic individuals work harder and become more unyielding. When narcissists fail, they try to prove that this failure arose from bad luck (Wallace \& Baumeister 2002; Dindar, 2020). An important aspect of narcissism is also that it has effect on team performance. Individuals with narcissistic personalities fail to become good team players. As they have no ability to empathize, they are inclined to perceive other human beings as a tool for their self-aggrandizement. As they view themselves as superior to other human beings, they act in a commanding manner in their interpersonal relationships. As they think that it is unlikely that their contributions to the team performance will be noticed, they perform way below their real potential in teamwork. The underperformance of narcissistic individuals which is below their real 
potential in teamwork is not well-received by other team members, and hence, the inclusion of narcissistic individuals into the team does not promote team's interests and gives rise to conflicts within the group (Wallace \& Baumeister, 2002).

There are several factors negatively affecting sportspeople's performance. The most important factors are undoubtedly anxiety and stress. With the help of different ways of thinking, sportspeople can cope with excessive stress and anxiety which affect their performance negatively. In anxious and stressful situations during which sportspeople have negative thoughts, sportspeople's performance is adversely affected. However, if sportspeople have a positive thinking framework to be used under adverse conditions which are likely to affect their performance negatively, they can cope with negative situations and achieve in performing better (Tazegül, 2018a).

Alongside various studies, it was inferred that successful sportspeople were those who were capable of coping with negative emotional situations (Tazegül, 2012). Hence, the higher the level of positive thinking of a tennis player is, the more the level of his/her life engagement goes up. Thus, tennis players who have high levels of positive thinking are able to cope more effectively with negative emotional situations (Tazegül, 2016; Tazegül, 2018b).

Individuals will get meaningful and valuable experiences only if they stick to their personal goals and have the confidence and determination to be activated for the purpose of reaching these personal goals. Attachment and confidence toward personal goals buttress individual's resilience against negative life experiences (Wrosch et al., 2003a).

Individual's conformist behaviors which are predicted to strengthen his/her life engagement and factors such as optimism, self-sufficiency and resilience which pave the way for reaching personal goals are interrelated with each other. The process of reaching valued personal goals will be accelerated if it is supported with such type of psychological constructs (Wrosch et al., 2003b).

Assuming that individuals have a limited period of time in the universe, it is also important to plan the available time productively and to organize future targets in an attainable and useful context because individuals who are confronted with several prospective developmental crises and missions across life (death of a loved one, divorce, migration, marriage, giving birth to a child) are required to have strong life engagement in order to cope with such situations. The promotion of life engagement is made up of a process directly or indirectly related to individual's life goals. Goals which enable individuals to give meaning to their lives and which facilitate their personal developments also play a role which is protective against psychological problems (Eryllmaz, 2012).

The objective of this study is to identify the relationship between life satisfaction and narcissism levels of students of the Physical Education and Sports School of Mardin Artuklu University.

\section{Methods}

\subsection{Research Model}

In this research, correlational survey model was utilized. The purpose of correlational survey model is to identify the relationship between two or more variables and the corresponding difference in variables.

\subsection{Research Group}

Population of the study was composed of Physical Education and Sports School students of Mardin Artuklu University. Sample of the study was comprised of 56 female and 99 male students who voluntarily agreed to participate in the study. Total number of students taking part in the study was 155.

\subsection{Methods of Data Collection}

\subsubsection{Satisfaction with Life Scale}

'Satisfaction with Life Scale' which was developed by Diener et al. (1985) was transformed into Turkish by Köker (1991) and Yetim (1991). This scale which measures the satisfaction with life contains five items and each item is scored as per seven options. Köker (1991) found the consistency coefficient as 0.85 in terms of the test-retest implemented for the scale at an interval of three months.

\subsubsection{Narcissistic Personality Inventory}

'Narcissistic Personality Inventory' was first created in 1979 by Raskin and Hall (1979). The Inventory was reorganized in a shorter format (NPI-16) in 2006 by Ames et al. In 2009, the Inventory was transformed into Turkish, and its validity and reliability test was performed by Salim Atay (2009). In the first study performed after the pilot study, Cronbach's Alpha coefficient was found by Atay as 0.57. As Cronbach's Alpha coefficient 
was found to be below the satisfactory level, the correlation of each factor with the Inventory was examined, and four items perceived negatively and ascertained to be irrelevant to the Inventory were revised. Along with this modification in the Inventory, Cronbach's Alpha coefficient was calculated as 0.65 in the validity and reliability test. In this case, Pearson correlation between narcissism scores of NPI-16 and NPI-15 was measured in order to find out whether it would be possible to use NPI version which contained 15 questions, and the correlation coefficient was ascertained as 0.987 . That is to say, along with the removal of an item with low correlation from the Inventory, Cronbach's Alpha coefficient for NPI-15 went up and its correlation with NPI-16 was maintained (Atay, 2009). In the validity and reliability test conducted in 2010 by Atay, Cronbach's Alpha coefficient was calculated as 0.713 .

\subsection{Data Analysis}

SPSS (Statistical Package for Social Science) 20.0 software was used in data analysis. One-sample Kolmogorov-Smirnov test was used in order to check whether data were normally distributed, and ANOVA Homogeneity of Variance test was utilized to assess the homogeneity of data. Along with the application of all these tests, it was found that data were homogenously and normally distributed. Independent Samples T-Test, One-way ANOVA and correlation analysis were utilized in data analysis.

\section{Results}

On the basis of data analysis, findings of the study are presented below.

Table 1. Comparison of means of scores obtained by participant students from the 'Narcissistic Personality Inventory' and 'Satisfaction With Life Scale' on the basis of gender variable

\begin{tabular}{cccccccc}
\hline \multirow{2}{*}{ Scale } & \multicolumn{5}{c}{ Gender } & \multirow{2}{*}{ P } & Result \\
\cline { 2 - 5 } & \multicolumn{2}{c}{ Female } & \multicolumn{2}{c}{ Male } & & \\
\cline { 2 - 5 } & Mean Score & SD & Mean Score & SD & & \\
\hline Narcissistic Personality Inventory & 7.574 & 3.875 & 7.325 & 3.014 & 0.733 & $\mathrm{p}>0.05$ \\
Satisfaction With Life Scale & 18.254 & 1.256 & 16.012 & 2.157 & 0.042 & $\mathrm{p}<0.05$ \\
\hline
\end{tabular}

As per statistical analysis, it was discerned that female students had higher narcissism scores than male students did, however, there was no statistically significant difference in means of scores obtained by female and male students from the Narcissistic Personality Inventory $(\mathrm{p}>0.05)$. On the other hand, it was found that female students had higher life satisfaction scores than male students did, and there was a statistically significant difference in means of scores obtained by female and male students from the Satisfaction With Life Scale $(\mathrm{p}=0.042, \mathrm{p}<0.05)$. The Found that female students of narcissism scores 7.574 , male students of narcissism scores 7.325; female students of life satisfaction scores 18.254, male students of life satisfaction scores 16.012

Table 2. Comparison of means of scores obtained by participant students from the 'Narcissistic Personality Inventory' and 'Satisfaction With Life Scale' on the basis of school department variable

\begin{tabular}{cccccccccc}
\hline \multirow{2}{*}{ Scale } & \multicolumn{4}{c}{ Departments of the Physical Education and Sports School } & & \multirow{2}{*}{ Result } \\
\cline { 2 - 7 } & \multicolumn{2}{c}{ Teaching } & \multicolumn{2}{c}{ Coaching } & \multicolumn{2}{c}{ Sports Management } & \multirow{2}{*}{ P } & & \\
\cline { 2 - 7 } & Mean Score & SD & Mean Score & SD & Mean Score & SD & & \\
\hline Narcissistic Personality Inventory & 6.012 & 4.382 & 7.644 & 4.633 & 7.567 & 4.659 & 0.366 & $\mathrm{p}>0.05$ \\
Satisfaction With Life Scale & 14.886 & 6.265 & 16.467 & 6.656 & 16.767 & 6.765 & 0.085 & $\mathrm{p}>0.05$ \\
\hline
\end{tabular}

As per statistical analysis, it was ascertained that students of Coaching Department had higher narcissism scores than students of Sports Management and Teaching Departments did, and students of Sports Management Department had higher life satisfaction scores than students of Coaching and Teaching Departments did. However, it was discerned that there was no statistically significant difference in means of scores obtained by students from the Narcissistic Personality Inventory and the Satisfaction With Life Scale on the basis of school department variable $(p>0.05)$. 
Table 3. Relationship between means of Narcissistic Personality Inventory and Satisfaction with Life Scale scores as per Pearson correlation analysis

\begin{tabular}{ccc}
\hline Pearson Correlation Analysis & Narcissistic Personality Inventory & $\mathrm{p}$ \\
\hline Satisfaction With Life Scale & 0.395 & 0.001 \\
\hline
\end{tabular}

As per Pearson correlation analysis, it was found that there was a moderately statistically significant positive relationship between means of scores obtained by students from Narcissistic Personality Inventory and Satisfaction with Life Scale.

\section{Discussion}

Findings of this study demonstrated that the mean of female students' narcissism scores (7.574 \pm 3.875$)$ was higher than the mean of male students' narcissism scores (7.325 \pm 3.014$)$. However, upon the comparison of means of female and male students' Narcissistic Personality Inventory scores, it was identified that there was no statistically significant difference $(\mathrm{p}=0.366, \mathrm{p}>0.05)$. As per the review of relevant literature, it was discerned that there were different studies either supporting or contradicting the findings of this current study. The study by Kaya and Kalkan (2019) found that male university students had higher narcissism scores than female university students did. The study by Özel (2014) ascertained that male students had higher narcissism scores than female students did. The study by Gezer (2017) found the mean of students' overall narcissism scores as $6.844 \pm 2.623$ points, and indicated that female students enrolled at Physical Education and Sports School had higher narcissism scores than female students did. This result is in support of this current study. The study conducted in 2017 by Özdemir found the mean of students' narcissistic personality scores as $7.100 \pm 1.63$ points. The study performed in 2019 by Arrkan and Filiz indicated that students of the Faculty of Sports Sciences had more narcissistic inclinations than students of the Faculty of Fine Arts did. Upon the literature review, it was discerned that studies conducted on students generally found that male students had higher narcissism scores, however, studies performed on students of the Physical Education and Sports School generally demonstrated that female students had higher narcissism scores. The most important reason for this finding is thought to be the 'sportive personality'. Along with sports, female students achieve in obtaining an aesthetical body perspective. It is supposed that this perspective has effects on the development of narcissistic personality by students because one of the most apparent narcissistic personality traits is the excessive interest in the body (Tazegül, 2018a). When this result was evaluated on the basis of narcissistic personality traits, it can be asserted that female students exhibited narcissistic personality traits more frequently, were egocentric and were more inclined to be at the forefront in the society.

Moreover, as per findings of this study, it was found that that the mean of female students' life satisfaction scores (18.254 \pm 1.256$)$ was higher than the mean of male students' life satisfaction scores $(16.012 \pm 2.157)$ and there was a statistically significant difference between female and male students $(\mathrm{p}=0.042, \mathrm{p}<0.05)$. Alongside the review of relevant literature, it was discerned that there were various studies either supporting or contradicting the findings of this current study on students' life satisfaction scores. The study by Tazegül (2018b) ascertained that the mean of scores obtained by tennis players from the Life Engagement Test was $25 \pm 4.78$ points. The study performed in 2017 by Tazegül found the mean of scores obtained by sportspeople from the Life Engagement Test as $17 \pm 2.261$ points. The study conducted in 2017 by Hanbay et al. asserted that male sportspeople had higher life satisfaction scores than female sportspeople did. The study carried out in 2017 by Özkan suggested that male sportspeople had higher levels of life satisfaction than female sportspeople did. The study performed on a total of 207 female and male sportspeople by Yildız et al. (2015) identified that female sportspeople had higher levels of life satisfaction than male sportspeople did. The study conducted for analyzing life satisfaction levels of students of Physical Education and Sports Schools on the basis of gender by Ulucan et al. (2011) found the mean of female and male students' life satisfaction scores successively as 15.55 and 14.17 points, and indicated that the difference between female and male students was statistically significant. Results of studies performed specifically on sportspeople are in support of findings of this current study. Departing from these findings, it can be suggested that female students enrolled at Physical Education and Sports Schools were more extrovert and enjoyed the life better.

Furthermore, upon the comparison of means of students' narcissism scores on the basis of departments of the Physical Education and Sports School, it was found that students of Coaching Department had the highest mean scores (7.644 \pm 4.633$)$, and they were followed by students of Sports Management Department (7.567 \pm 4.659$)$ and students of Teaching Department (6.012 \pm 4.382 ). Besides, alongside the comparison of means of students' life satisfaction scores on the basis of departments of the Physical Education and Sports School, it was discerned that

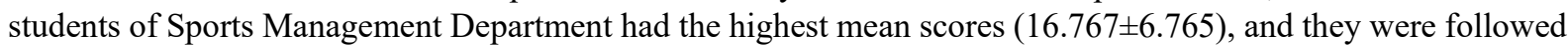

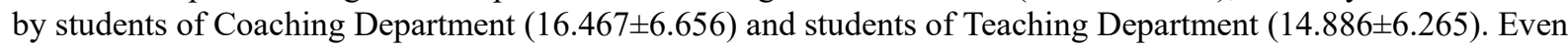


though rankings of departments differed across two measurement tools, it was ascertained that there was no statistically significant difference both in means of narcissism scores and in means of life satisfaction scores on the basis of department variable ( $>0.05$ ). The study carried out by Bayrak et al. in 2015 for comparing narcissistic personality scores of Physical Education and Sports School students exhibited that there was no statistically significant difference in means of scores obtained by students of Teaching, Coaching and Sports Management Departments from Superiority, Exhibitionism, Entitlement, Self-sufficiency Factors of Narcissistic Personality Inventory ( $p>0.05$ ). This result is in support of the finding of this current study. The study performed by Ulucan et al. (2011) for comparing life satisfaction levels of 230 students of Physical Education and Sports Schools of two different universities on the basis of school department variable ascertained that there was a statistically significant difference between departments. In this current study, it was observed that there was no statistically significant difference in students' life satisfaction levels between departments of the school. It is estimated that the divergence in findings arises from differences in sampled groups.

Lastly, as per Pearson correlation analysis, it was found that there was a moderately statistically significant positive relationship between means of students' life satisfaction and narcissism scores (Correlation coefficient $=0.395$ ). The study conducted in 2019 by Tozar indicated that there was a negative relationship between narcissism and life satisfaction scores of university students. It is supposed that the divergence in findings of the study by Tozar and this current study arises from differences in sampled groups. Several studies performed in Europe found that there was a relationship between narcissism and life satisfaction levels (Bourbonnais \& Durand 2018; Aghababaei \& Blachnio 2015). When these statistical findings are assessed on the basis of life satisfaction and narcissistic personality traits, it is thought that it is normal to obtain this result because narcissistic individuals enjoy life better along with being at the forefront and fulfilling their aspirations.

\section{Conclusion}

In conclusion, it was found that female students had higher narcissism and life satisfaction scores than male students did. Thus, it was inferred that female students behaved more narcissistically and were more engaged with life. Moreover, upon the comparison of students' narcissism and life satisfaction scores on the basis of departments of Physical Education and Sports School at which they were enrolled, it was ascertained that there was no statistically significant difference either in means of narcissism scores or in means of life satisfaction scores.

\section{References}

Aghababaei, N., \& Błachnio, A. (2015). Well-being and the Dark Triad. Personality and Individual Differences, 86, 365-368. https://doi.org/10.1016/j.paid.2015.06.043

Ames, D. R., Rose P., \& Anderson, C. P. (2006). The NPI-16 as a short measure of narcissism. Journal of Research in Personality, 40(4), 440-450. https://doi.org/10.1016/j.jrp.2005.03.002

Arıkan, N., \& Filiz, B. (2019). Spor Bilimleri Fakültesi Öğrencileri İle Güzel Sanatlar Bölümü Öğrencilerinin Narsistik Kişilik Özelliklerinin Karşılaştırılması. Eğitim Bilimlerinde Akademik Çalışmalar-2019/2. Cetinje.

Atay, S. (2009). Narsist Kişilik Envanterinin Türkçeye Standardizasyonu. Gazi Üniversitesi İktisadi ve İdari Bilimler Fakültesi Dergisi, 11(1), 181-196.

Atay, S. (2010). Çallşan narsist örgütler, liderler, yöneticiler ve astlar. İstanbul: Namar Yayınları.

Bayrak, E., Gacar, A., Nacar, E., \& Aytaç, K. Y. (2015). Beden Eğitimi ve Spor Yüksekokulu Öğrencilerinin Narsistik Kişilik Özelliklerinin İncelenmesi. The Journal of Academic Social Science, 3(14), 249-261. https://doi.org/10.16992/ASOS.698

Bourbonnais, K., \& Durand, G. (2018). The incremental validity of the Triarchic model of psychopathy in replicating "The dark side of love and life satisfaction: Associations with intimate relationships, psychopathy and Machiavellianism". The Quantitative Methods for Psychology, 14(3), 12-17. https://doi.org/10.20982/tqmp.14.3.r001

Campbell, W. K., Goodie, A. S., \& Foster, J. D. (2004). Narcissism, confidence, and risk attitude. Journal of Behavioral Decision Making, 17, 297-311. https://doi.org/10.1002/bdm.475

Diener, E., Emmons, R. A., Larsen, R. J., \& Griffin, S. (1985). The Satisfaction with Life Scale. Journal of Personality Assessment, 49(1), 71-75. https://doi.org/10.1207/s15327752jpa4901_13

Dindar, M. D. (2020). Comparing Burnout Levels of Natıonal Athletes According To Several Variables. Sylwan, 164(2), 236-242. 
Eryılmaz, A. (2012). Pozitif psikoterapi bağlamında yaşam amaçları belirleme ölçeğinin üniversite öğrencileri üzerinde psikometrik özelliklerinin incelenmesi. Klinik Psikiyatri, 15, 166-174.

Gezer, E. (2017). Beden Eğitimi Ve Spor Yüksekokulu Öğrencilerinin Narsistik Eğilimleri. Journal of International Social Research, 10(53). https://doi.org/10.17719/jisr.20175334145

Gürkan, A. C., Yıldız, M., Çalışkan, G., \& Dinç, A. (2018). Üniversite Öğrencilerinin Spor Yapma Alışkanlıkları İle Narsistik Kişilik Özellikleri Arasındaki İlişkinin Değerlendirilmesi. Akademik Sosyal Araştırmalar Dergisi, 6(85), 21-34. https://doi.org/10.16992/ASOS.14476

Hanbay, E., Keskin, B., \& Kahrıman, M. (2017). Spor Yapan Bireylerin Yaşam Doyumlarının Araştırılması. Journal of International Social Research, 10(51). https://doi.org/10.17719/jisr.2017.1858

Kaya, L., \& Kalkan, M. (2019). Üniversite Öğrencilerinde Narsisistik Eğilimler, Bağlanma Stilleri Ve Sosyal Medya Kullanım.. Journal of Higher Education \& Science/Yüksekögretim ve Bilim Dergisi, 9(2).

Köker, S. (1991). Normal ve sorunlu ergenlerin yaşam doyumu düzeylerinin karşılaşstırlması. Yayınlanmamış yüksek lisans tezi, Ankara Üniversitesi Sosyal Bilimler Enstitüsü.

Morf, C. C., \& Rhodewalt, F. (2001). Unravelling the paradoxes of narcissism: A dynamic self-regulatory processing model. Psychological Inquiry, 12, 177-196. https://doi.org/10.1207/S15327965PLI1204_1

Özdemir, H. E. (2017). Bir Grup Üniversite Öğrencisinde Bağlanma Stilleri İle Narsisizm Arasındaki İlişki: Reddedilme Duyarlılığının Aracı Rolü. Hacettepe Üniversitesi, Edebiyat Fakültesi, Psikoloji Bölümü; Yüksek Lisans Programı.

Özel, İ. (2014). Dindarlarda Narsizm: Yüksek Din Eğitimi Alan Öğrenciler Üzerine Bir Araştırma. Journal of International Social Research, 7(32).

Özkan, S. N. (2017). Spor Yapan Bireylerin Yaşam Doyumlarının Demografik Değişsenler Açısından Araştırılması. İÜ Beden Eğitimi ve Spor Yüksekokulu, Lisans Programı Bitirme Projesi İstanbul.

Raskin, R. N., \& Hall, C. S. (1979). A narcissistic personality inventory. Psychological Reports, 45(2), 590. https://doi.org/10.2466/pr0.1979.45.2.590

Saydam, B. (1996). Narsisistik kişilik bozukluğu, antisosyal kişilik bozukluğu, borderline kişilik bozukluğu: Psikodinamik açıdan benzerlikler, farklılıklar. Ege Psikiyatri Sürekli Yayınları, 3, 413-430.

Tazegül, Ü. (2012). Bireysel Sporcuların Stresle Başa Çıkma Tarzlarının Karşılaştırılması. Journal of Sports and Performance Researches, 3(2), 13-22.

Tazegül, Ü. (2016). Elit Düzeydeki Tenisicilerin Yaşama Bağlllık Düzeyleri İle Bedenlerini Beğenmeleri Arasındaki İlişkinin Belirlenmesi. The Journal of Academic Social Science, 4(32), 468-474. https://doi.org/10.16992/ASOS.3456

Tazegül, Ü. (2017). Sporcuların Kişilik Özellikleri İle Yaşama Bağlılıkları Arasındaki İlişsinin Belirlenmesi. The Journal of Academic Social Science, 5(39), 587-594. https://doi.org/10.16992/ASOS.11903

Tazegül, Ü. (2018a). Spor, Narsisizm ve Beden Algısı. Detay Yayınc1lı, Ankara.

Tazegül, Ü. (2018b). Elit Düzeydeki Tenisçilerin Olumlu Düşünme ve Yaşama Bağl1lık Düzeyleri Arasındaki İlişkinin Belirlenmesi. Akademik Bakış Uluslararası Hakemli Sosyal Bilimler Dergisi, 67, 16-25.

Tazegül, Ü., \& Ferah, M. (2016). The Determınatıon Of The Relatıonshıp Between Sports Age And The Levels Of Narcissism Levels Of Female Athletes. European Journal of Physical Education and Sport Science, 2(4), 36-44.

Timuroğlu, M. K. (2005). İşyerinde narsisizm ve iş tatmini ilişkisi: Bir uygulama. Yayınlanmış Yüksek Lisans Tezi, Atatürk Üniversitesi Sosyal Bilimler Enstitüsü, Erzurum.

Tozar, M. Z. (2019). Karanlık Üçlü Kişilik Özelliklerine Göre Üniversite Öğrencilerinin Yaşam Doyumları. Yayınlanmış Yüksek Lisans Tezi, Eğitim Bilimleri Ana Bilim Dalı Psikolojik Danışma ve Rehberlik Program1, Hacettepe Üniversitesi.

Ulucan, H., Kılınç, M., Kaya, K., \& Türkçapar, Ü. (2011). Beden Eğitimi Spor Yüksekokullarında Öğrenimlerine Devam Eden Öğrencilerin Umutsuzluk ve Yaşam Doyum Düzeylerinin İncelenmesi. Selçuk Üniversitesi Beden Eğitimi ve Spor Bilim Dergisi, 13(3), 349-356.

Wallace, H. M., \& Baumeister, R. F. (2002). The performance of narcissists rises and falls with perceived opportunity for glory. Journal of Personality and Social Psychology, 82(5), 819-834. 
https://doi.org/10.1037/0022-3514.82.5.819

Wrosch, C., Scheier, M. F., Carver, C. S., \& Schulz, R. (2003a). The importance of goal disengagement in adaptive self-regulation: When giving up is beneficial. Self Identity, 2, 1-20. https://doi.org/10.1080/15298860309021

Wrosch, C., Scheier, M. F., Miller, G. E., Schulz, R., \& Carver, C. S. (2003b). Adaptive self-regulation of unattainable goals: Goal disengagement, goal re engagement, and subjective well-being. Personality and Social Psychology Bulletin, 29, 1494-1508. https://doi.org/10.1177/0146167203256921

Yetim, Ü. (1991). Kişisel projelerin organizasyonu ve örüntüsü açısından yaşam doyumu. Yayınlanmamış doktora tezi, Ege Üniversitesi, Sosyal Bilimler Enstitüsü.

Yıldız A. B., Gülşen D. B., \& Yılmaz B. (2015). Sporcuların Optimal Performans Duygu Durumunun Yaşam Tatminleri Üzerindeki Etkisi. Niğde Üniversitesi Beden Eğitimi Ve Spor Bilimleri Dergisi, 9, 58-64.

\section{Copyrights}

Copyright for this article is retained by the author(s), with first publication rights granted to the journal.

This is an open-access article distributed under the terms and conditions of the Creative Commons Attribution license (http://creativecommons.org/licenses/by/4.0/). 